\section{Monitoring recent variations of the surface displacements of eight Nyainqêntanglha glaciers}

\section{Surface \\ displacements, Nyainqêntanglha glaciers \\ J. Shi and M. Menenti}

Title Page

\section{J. Shi and M. Menenti}

Department of Geoscience and Remote Sensing, Faculty of Civil Engineering and Geosciences, Delft University of Technology, Delft, the Netherlands

Received: 20 December 2013 - Accepted: 9 January 2014 - Published: 5 February 2014 Correspondence to: J. Shi (junchao.shi@tudelft.nl)

Published by Copernicus Publications on behalf of the European Geosciences Union.
Abstract Introduction

Conclusions References

Tables Figures

14

4

Back 


\section{Abstract}

A polythermal glacier is one of the dominant types of glacier that is distributed widely in the transition zone of the monsoon and continental climates of the Tibetan Plateau. However, the study of the glacier dynamics of this type of glacier in most of the glaciated

5 area is still limited owing to the remoteness of the mountains, and issues related to high altitude. Theoretically, the surface displacement of a polythermal glacier has strong variations both in the spatial and temporal scales. We chose eight typical polythermal type glaciers (Zhadang Glacier, Panu Glacier, Lalong Glacier, Tangse No. 2 Glacier, Xibu Glacier, Lisheng Glacier, Guila Glacier, and Guren Glacier) in the Nyainqêntan-

glha Mountains, the south of Nam Co Lake, Tibetan Plateau for a case study. In this study, we monitored the ice surface displacements of these glaciers for nearly two decades from 1993 to 2009 by using the feature-tracking method. The ice displacement measurements with sub-pixel accuracy were recorded over the entire areas of the Zhadang, Panu, Lalong, Tangse No. 2, Xibu, Lisheng, Guila, and Guren glaciers during this period. Through the comparison of ice surface displacements between 1993-2003 and 2003-2009, we found that the change of the displacements are observed in most areas of these studied glaciers, especially in the ablation zones. The magnitude of this change is about $-51 \%$, except in the Xibu Glacier ( $+24 \%$ ), in terms of the average of the total displacements. The surface displacements that were extracted by spaceborne optical imagery are promising for potential detection of the mechanics of polythermal glaciers in the Nyainqêntanglha Mountains.

\section{Introduction}

It is known that gravity driven basal sliding is one of the dominant controllers for glacier and ice sheet movement. However, the mechanical characteristics of ice, which depend on the temperature, largely affect ice deformation coupling the flow dynamics. This implies that both the thermal fluxes from the surface climate and the basal geothermal
HESSD

$11,1555-1581,2014$

Surface

displacements, Nyainqêntanglha

glaciers

J. Shi and M. Menenti

Title Page

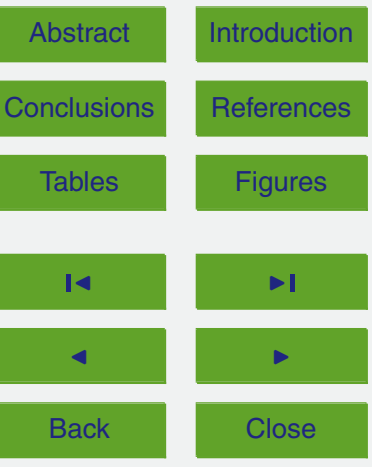

Full Screen / Esc

Printer-friendly Version

Interactive Discussion 
heat will conduct into the body of ice, reshape the distribution of internal temperature of ice, then change the ice flow patterns gradually. Glacier, especially a mountainous glacier, is more confined by its bed topography and is relatively smaller, when compared to the ice sheet in the polar area. Except in the surging state, the displacement 5 of a glacier is smaller than an order of hundreds of meters per year (Hutter, 1982; Hutter et al., 1988). Based on the thermal regime of a glacier, the polythermal glacier is one of the widely distributed glaciers that is found from the polar regions (e.g., glaciers in Greenland, Alaska, and Scandinavia) to the mountainous zones (e.g., glaciers in the Alps, and the Tibetan Plateau) (Blatter and Hutter, 1991). Conceptually, the ice body 10 of a polythermal glacier is assumed to made of several disjointed parts (cold part, temperate part, and so on). Moreover, subglacial hydrology and thermal exchange of the interface (including surface and basal boundary) are thought to be the two operators of flow dynamics (Fowler and Larson, 1980; Copland et al., 2003; Aschwanden and Blatter, 2009).

15 Through the monitoring of the variations of surface displacement, the deformational and basal processes that occur on glaciers can be further understood. For instance, surface displacement measurement is a moderate indicator of the state of flow in motion during distinct climatological conditions when the ice body moves at the temperate base. In other words, derivations of glacier surface motions can be helpful to recognize the roles of the melting and sliding process, and the partitions of the structures of polythermal glaciers. A polythermal glacier is one of the dominant types of glacier that is distributed widely in the transition zone of the monsoon and continental climates of the Tibetan Plateau (Shi and Liu, 2000; Shi et al., 2009). Over the past decades, the fluctuations of ice motion were observed at some polythermal ice masses across the polar areas and mountains. However, similar studies in the Tibetan glaciers are still limited due to the high altitude and other complicated geoenvironmental conditions. Since the 1950s, glaciologists have paid attention to this issue through a combination of thermometers, steam drill, and other repetitive terrestrial surveying methods. Abundant temperature data of ice bodies were recorded on various glaciers over the entire

\section{HESSD}

$11,1555-1581,2014$

Surface

displacements,

Nyainqêntanglha

glaciers

J. Shi and M. Menenti

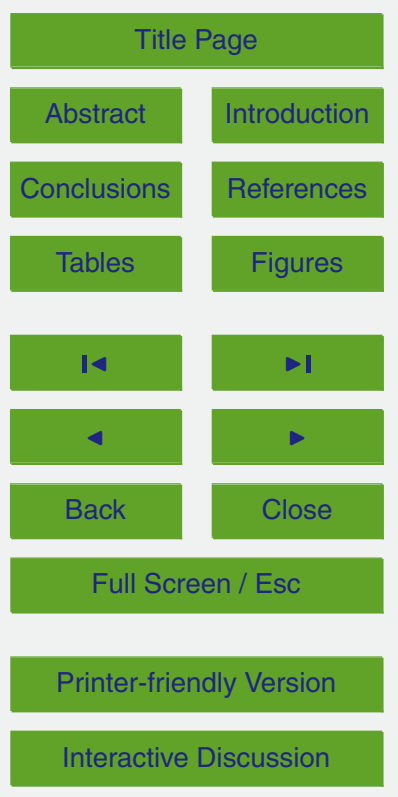


Tibetan Plateau for a long period. Vertical profiles of temperature from the surface to the bed, of the studied polythermal glaciers were measured along with the melting base and sub-freezing temperature in the relative upper layers (Huang, 1990). A glacier inventory was gradually established through airborne, and spaceborne optical imageries 5 and topographical maps during the following decades to estimate the situation of the glaciers dynamics (Wang and Yang, 1992; Shi et al., 2009).

\section{Study area}

In this study, we focus on the glaciated area in the transition of the monsoon and continental climates that dominate the mountain range of the Nyainqêntanglha Mountains, in particular. Approximately $90 \%$ of the annual precipitation becomes the main input of the glacier mass in summer. Specifically, the glaciers in this area accumulate and shrink with the maximum of annual accumulation and ablation that occurs simultaneously during the summer season (Kang et al., 2007). Based on previous estimations that used imageries of Landsat TM/ETM+ etc., the total area of glaciers suited in this 15 mountain range was $795.6 \pm 22.3 \mathrm{~km}^{2}$ until 2001. The area of some sampled glaciers (Zhadang, Tangse No. 2, Lalong, Xibu, Panu, see Fig. 1) reduced by $-6.1 \pm 3 \%$ during the period of 1976-2001. On the other hand, there no advancing was detected in these sampled glaciers; the magnitude of the glacier length was about $10 \mathrm{~m}$ per year on average between 2001 and 2009. It was also observed that, the ice cover corresponding to

the monsoon wind direction, and the temperature fluctuation were probable triggers for glacier shrinkage (Bolch et al., 2010). The details of these selected glaciers are shown in Table 1.

\section{HESSD}

$11,1555-1581,2014$

Surface

displacements, Nyainqêntanglha

glaciers

J. Shi and M. Menenti

Title Page

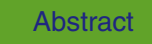

Introduction

Conclusions

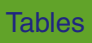

References

Tables

Figures

14

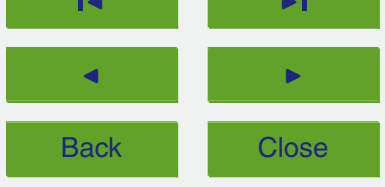

Full Screen / Esc

Printer-friendly Version

Interactive Discussion 


\section{Data and methodology}

\subsection{Data}

Since Landsat-4 launched in 1982, the Thematic Mapper (TM) class of Landsat (Landsat 4,5 , and 7 ) sensors has been responsible for providing good-quality multispectral

5 imagery appropriate for many different applications (Markham et al., 2004). However, the artifacts by such as memory effect (ME), scan-correlated shift (SCS), and coherent noise $(\mathrm{CN})$ are attenuating the capable information derived from Landsat imageries as well. The radiometric and geometric calibrations and corrections are considered as the essential procedures to remove those instrument artifacts and atmospheric path degradation from Landsat data (Vogelmann et al., 2001). To address these calibrations and corrections issues, the Level 1 Product Generation System (LPGS) are applied for the standard product of Landsat currently. Initially, all the raw imageries acquired by Landsat Ground System (LGS) from Landsat TM sensor are reformatted into LOR data. The image data, Payload Correction Data (PCD), Mirror Scan Correction Data (MSCD), calibration data and metadata are attached together. Then, the user request for the higher level products of Landsat scenes are processed through Standard Terrain Correction (Level 1T - with better precision and terrain correction) if necessary. In the case of without ground-control or elevation data necessary for L1T correction, the Level $1 \mathrm{G}$ (with only systematic correction) or Level 1Gt (with systematic terrain correction) is the best level of correction applied to the imageries (Williams et al., 2006). The radiometric and geometric accuracy of Landsat data can be achieved systematically by Standard Terrain Correction combining ground controls points while employing a Digital Elevation Model (DEM) in the product Level 1T. In particular, DEMs including Shuttle Radar Topography Mission (SRTM), National Elevation Dataset (NED), Canadian Digital Elevation Data (CDED), and Global 30 Arc-Second Elevation (GTOPO 30) with Ground control points from the GLS 2000 dataset are devoted to geodetic accuracy of the production. Eventually, the Landsat standard product are accomplished with geotiff format, moderate resolution (30 m-TM, ETM+ and $60 \mathrm{~m}$-MSS) after applying the

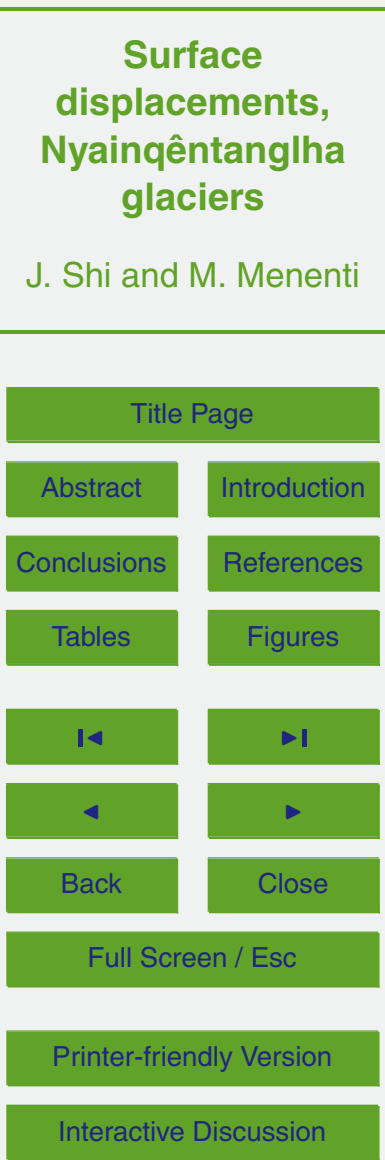

1559 
Cubic Convolution (CC) resampling, projection and map (north-up) image orientation procedures (Wulder et al., 2008; Chander et al., 2009).

Owing to the summer - accumulation regime of the glacier mass mentioned in the above section, three Landsat imageries (14 January 1993, 18 November 2003, and

518 January 2009) obtained in the winter season were chosen for the glacier surface displacement study. This choice can considerably avoid the attenuation of imageries by clouds and precipitation. The used Landsat imageries are categorized as Landsat TM Level 1T products. All the imageries have been removed of terrain-induced artifacts and georeferenced as well.

\subsection{Feature-tracking method}

According to the developments of the spaceborne optical imagery datasets, more and more ice flow dynamics are studied by optical feature tracking techniques on the Tibetan Plateau. Compared with the InSAR technique, feature-tracking methods of optical imageries are more useful for tremendous ice surface displacements monitoring in the long term. In general, surface displacements are obtained by tracking the certain surface features (such as, debris, moraine etc.) of the glacier on two different dates. Specifically, the core of this technique is image matching. Since the 1980s, various feature-tracking methods based on distinct image matching were developed and applied for a number of case studies over the globally glaciated area (Heid and Kääb, 2012). In the earlier period, Lucchitta and Ferguson (1986), and Doake and Vaughan (1991) described the potential of the sequential spaceborne imageries through their studies on the ice shelf, and glaciers of Antarctica. Then, the normalized cross-correlation feature tracking was developed for the velocity extraction of the polar ice flow and other glaciated regions by Bindschadler and Scambos (1991) and 25 Scambos et al. (1992). In this method, the features are limited in a rectangular window, rather than in an individual pixel. This improvement yields accuracy of displacement from the pixel size to better resolution and higher density of the final velocity measurements. This algorithm was adapted for ice velocity and surge dynamic studies on the

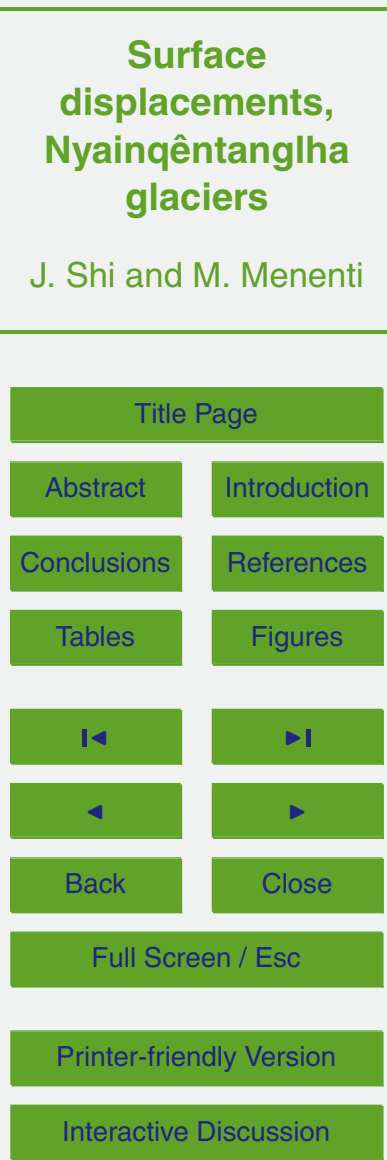


Tibetan Plateau by Copland et al. (2009) and Quincey et al. (2009a, 2011). Inspired by this algorithm, distinct feature-tracking methods are being developed sequentially, and some of them are implemented through the cross-correlation in the spatial domain, or least squares matching, and the others are implemented in the frequency domain (Heid 5 and Kääb, 2012). Here, we choose one of the feature-tracking methods developed by Leprince et al. (2007, 2008), whose emphasis is not only on the orthorectification and the coregistration for one pair of repeated imageries, but also on the certain phase correlation algorithm. It implies that the phase distinction estimation of this method is implemented in the frequency domain. Meanwhile, the moving window size of this 10 method is relatively smaller than the other methods, which can be more suitable for a roughened ice surface (crevasses, marine covered parts etc.). Recent studies show that this method is widely applied for glacier dynamic studies in the Tibetan glaciers, such as for surge behaviors of glaciers in the Karakoram mountain range and variations of the Himalayan types glaciers (Scherler et al., 2008; Quincey et al., 2009b; Scherler et al., 2011; Scherler and Strecker, 2012). Nevertheless, as a polythermal type glacier is distributed in the wide area, the lack of ice surface displacement observations is significant in the Nyainqêntanglha Mountains.

In this study, the phase-correlation based feature-tracking method is used. During each displacement derivation process, the overlapping part of the two repeated imageries is prepared for correlation in the Fourier domain. Here, we assume $i_{\mathrm{m}}$ and $i_{\mathrm{s}}$ as the originally master image and the shifted version of the master image (slave), which differ by the relative displacement $\left(\Delta_{x}, \Delta_{y}\right)$, thus

$i_{\mathrm{m}}(x, y)=i_{\mathrm{s}}\left(x-\Delta_{x}, y-\Delta_{y}\right)$

25 According to the Fourier shift theorem, we deduce the relation between the Fourier transforms $I_{\mathrm{m}}, I_{\mathrm{s}}$ of the original images $i_{\mathrm{m}}$ and $i_{\mathrm{s}}$, and as below

$I_{\mathrm{m}}\left(\omega_{x}, \omega_{y}\right)=I_{\mathrm{s}}\left(\omega_{x}, \omega_{y}\right) e^{-j\left(\omega_{x} \Delta_{x}+\omega_{y} \Delta_{y}\right)}$

HESSD

$11,1555-1581,2014$

Surface

displacements,

Nyainqêntanglha

glaciers

J. Shi and M. Menenti

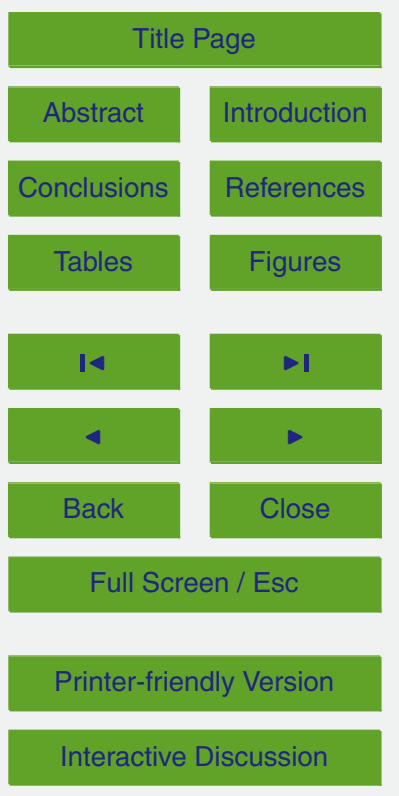


$\omega_{x}-$ the frequency variable in column;

$\omega_{y}-$ the frequency variable in row.

$11,1555-1581,2014$

when $*$ refers to the complex conjugate, the normalized cross-spectrum of the original images $i_{\mathrm{m}}$ and $i_{\mathrm{s}}$ can be turned out as

$C_{i_{m}, i_{s}}\left(\omega_{x}, \omega_{y}\right)=\frac{I_{m}\left(\omega_{x}, \omega_{y}\right) I_{s}^{*}\left(\omega_{x}, \omega_{y}\right)}{\left|I_{m}\left(\omega_{x}, \omega_{y}\right) I_{s}^{*}\left(\omega_{x}, \omega_{y}\right)\right|}=e^{j\left(\omega_{x} \Delta_{x}+\omega_{y} \Delta_{y}\right)}$

Then, the displacement of these two imageries (master, and slave) can be derived by measuring the phase difference of each imagery's Fourier transform within the sliding correlation window by starting from upper-left corner of the scene. Alternatively, it can be demonstrated that the 2-D slope of the cross-spectrum's phase is a good estimation of the displacement of the two correlated imageries,

$\mathcal{F}^{-1}\left\{e^{j\left(\omega_{x} \Delta_{x}+\omega_{y} \Delta_{y}\right)}\right\}=\delta\left(x+\Delta_{x}, y+\Delta_{y}\right)$

Title Page

displacements, Nyainqêntanglha

glaciers

J. Shi and M. Menenti

where $\mathcal{F}^{-1}$ refers to the inverse Fourier transform.

In practice, the relative images' shift is derived by explicitly estimating the linear phase of the images' cross-spectrum. An robustness iterations (TPSS algorithm) is embedded to search the precise estimation of $\left(\Delta_{x}, \Delta_{y}\right)$ with respect to the specified constrains as follows:

$20\left\{\begin{array}{l}Q^{i+1}\left(\omega_{x}, \omega_{y}\right)=Q^{i}\left(\omega_{x}, \omega_{y}\right) e^{-j\left(\omega_{x} \Delta_{x}^{i}+\omega_{y} \Delta_{y}^{i}\right)} \\ \varphi_{\Delta}^{i}\left(\omega_{x}, \omega_{y}\right)=W^{i}\left(\omega_{x}, \omega_{y}\right)\left|Q^{i}\left(\omega_{x}, \omega_{y}\right)-C^{i}\left(\omega_{x}, \omega_{y}\right)\right|^{2} \\ W^{i+1}\left(\omega_{x}, \omega_{y}\right)=W^{i}\left(\omega_{x}, \omega_{y}\right)\left(1-\frac{\varphi_{\Delta}^{i}\left(\omega_{x}, \omega_{y}\right)}{4}\right)\end{array}\right.$

Conclusions

Tables

Introduction

References

Figures

14

$>1$

$<$

Back

Close

Full Screen / Esc

Printer-friendly Version

Interactive Discussion 
where $Q\left(\omega_{x}, \omega_{y}\right)$ and $C\left(\omega_{x}, \omega_{y}\right)$ refer to the normalized cross-spectrum computed from the images and the theoretical one, $W$ is the some weighting matrix with positive entries. Then we get the global shift between the two images:

$$
\left\{\begin{array}{l}
\Delta_{x}=\sum_{i} \Delta_{x}^{i} \\
\Delta_{y}=\sum_{i} \Delta_{y}^{i}
\end{array}\right.
$$

When the displacements are derived, a filtering procedure is implemented to remove the outliers initially. To keep all the comparable pixels within the corresponding displacement map, we culled out all the displacement pixels based on the geolocations of these displacement pixels within a polythermal glacier. To acquire the statistical properties of the displacements on each polythermal glacier, all the selected displacements were used for calculating their necessary statistics, including the PDF (probability density function), average, and maximum. Finally, all the resultant displacements, differences of displacements (1993-2003, 2003-2009) were resampled to a considerate resolution $(90 \mathrm{~m} \times 90 \mathrm{~m})$ by the bilinear method for the studied glaciers (for more details of the processing steps, see Leprince et al., 2007; Heid and Kääb, 2012 and Fig. 2).

\section{Surface displacement observations}

In this section, we focus on the displacements that occurred on the chosen polythermal glaciers, namely, Zhadang, Tangse No. 2, Lalong, Xibu, Panu, Guren, Guila and Lisheng. On one hand, the area of the largest glacier (Xibu) remains about $\sim 22.9 \mathrm{~km}^{2}$ when compared with the smallest one (Zhadang is merely about $2.36 \mathrm{~km}^{2}$ ) among all these glaciers until 2009, due to the long-term glaciological investigations. On the other hand, the measured rate of the retreated length reaches a much higher percentage of $-14.2 \%$ on the Zhadang Glacier than $-1.9 \%$ on the Xibu Glacier within the period of 1976-2009 (Kang et al., 2007; Shi and Liu, 2000; Caidong and Asgeir,

\section{HESSD}

$11,1555-1581,2014$

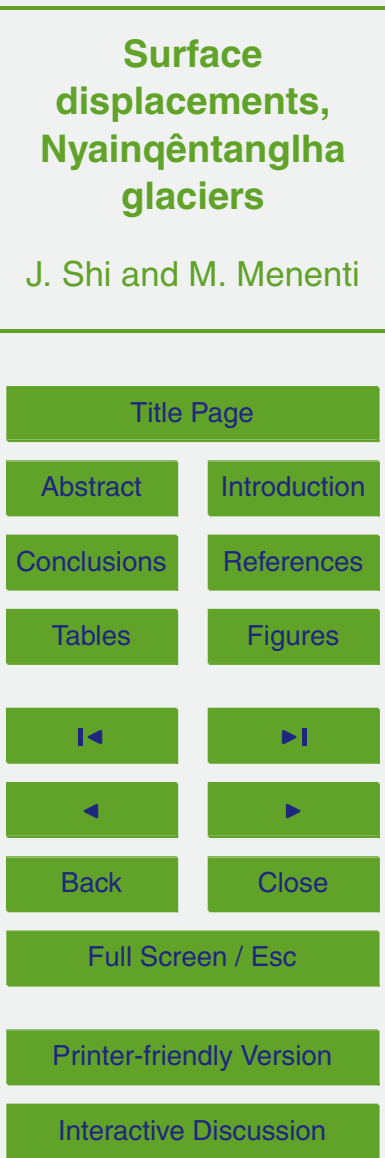


2010; Bolch et al., 2010). Time series meteorological observations on both Zhadang Glacier and Lalong Glacier have been established. The characteristic records of all these glaciers were accumulated by CAS (Chinese Academy of Sciences) including aerophotos, GPS, etc. since the 1970s (Kang et al., 2009; Shi et al., 2009).

5 Totally, 16 displacement maps for eight glaciers were derived from the first part of the processing chain. From our estimation, all these eight glaciers are in an active state during both the 1993-2003 and 2003-2009 periods. Depending on the initial filtering procedure of the processing chain, the valid pixels that remain, in the studied glaciated area, were about 9668 in 1993-2003, while only 9575 pixels were left in 2003-2009. 10 In the first period, the derived displacements imply that the largest recorded displacement of the Xibu Glacier reached $425.60 \mathrm{~m}$. It is almost $\sim 2$ times the magnitude lager than the recorded maximums on the other seven glaciers. Similarly, this largest displacement of the Xibu Glacier, which is still the largest among all the eight glaciers considered, increases to $477.69 \mathrm{~m}$ in the second period. Then, we calculated the average and maximum of the displacements for each glacier in these two periods, which are shown in Fig. 3. The results indicate that the average of the displacements of each glacier decreases from 20 to 60\%, except for the Xibu Glacier (+24\%) (see Table 2). Moreover, the largest decrease of the displacement average is observed at $-65 \%$ of the magnitude on the Guren Glacier.

To compare the differences and distributions of the displacements of these glaciers in both the periods, we culled out all the common pixels on each glacier based on the geolocations of the pixels. Some pixels, such as the maximum displacement of the Xibu Glacier in each period, were excluded and the final maximum displacement of the Xibu Glacier was $413 \mathrm{~m}$ during the period 1993-2003 (Fig. 4a), $403 \mathrm{~m}$ during the period 2003-2009 (Fig. 4b). The PDF (probability density function) of the displacement was derived for each glacier during both the periods (see Figs. 5 and 6). Next, we generated the scatter plots to estimate the distributions of displacement magnitude for each glacier (periods 1993-2003 and 2003-2009) (see Fig. 7). The magnitude of displacement of one glacier in the different periods can be clearly compared for each certain

\section{HESSD}

$11,1555-1581,2014$

Surface

displacements,

Nyainqêntanglha

glaciers

J. Shi and M. Menenti

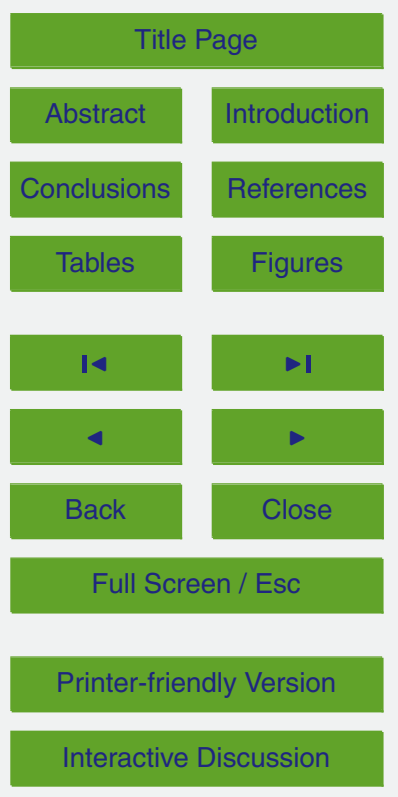


pixel in the figure. There are apparently discrete trends of displacements in the two periods for all the eight glaciers. At the same time, clustering trends are observed in the relatively small magnitude zone on the Guila Glacier, Lalong Glacier, Panu Glacier, and Xibu Glacier, which also correspond well to the PDFs shown in the auxiliary mate5 rials, (Figs. 2, and 3). Furthermore, we estimated the differences of the displacements in the two periods for each glacier (see Fig. 8). The partition of the decreased displacement pixels is almost larger than the increased displacement pixels except for the Xibu Glacier. Over $60 \%$ of the absolute deviation of these two displacements (for the periods 1993-2003, and 2003-2009) of each glacier falls between $40 \mathrm{~m}$ and $200 \mathrm{~m}$.

10 Consequently, we resampled all the selected pixels to the final displacement maps as well as the differences of the displacement map in these 2 periods at $90 \mathrm{~m} \times 90 \mathrm{~m}$ resolution (see Figs. 4 and 9). In terms of glaciology, the values of the displacements in the period 1993-2003 are higher than the values in 2003-2009. Secondly, the relatively larger displacements $(>50 \mathrm{~m}$ ) in both the periods are detected in the terminus and ablation zones. These findings match the retreat behaviors of the glaciers in this mountain range that were detected by previous studies (Kang et al., 2007; Caidong and Asgeir, 2010; Bolch et al., 2010).

\section{Discussion}

In general, both basal sliding and ice melting that are induced by thermal and hydro20 ice flow (basal sliding/internal deformation) can also be revealed from the spatial distribution of surface displacement observations. Specifically, ice melting regulates the internal deformation by the conduction and transfer of heat within the ice mass (Blatter and Hutter, 1991). In this study, the displacements relatively remain a considerable in terms of magnitude in almost entire ablation zone of the studied polythermal glaciers in the Nyainqêntanglha Mountains. On average, this displacement value is $>45 \mathrm{~m}$ from 1993 to 2003 and > 20 m from 2003 to 2009 (see Fig. 4). Moreover, the relatively large

\section{HESSD}

11, 1555-1581, 2014

Surface

displacements,

Nyainqêntanglha

glaciers

J. Shi and M. Menenti

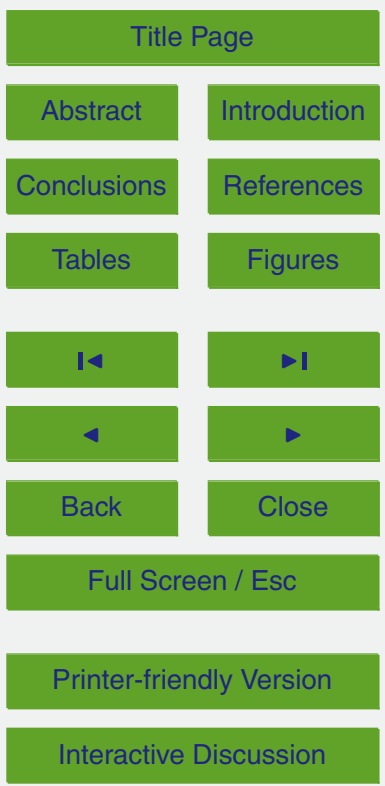


displacements found on the Guila, Guren, Panu and Lisheng vary stably from the center to the margins of the ablation zone. There is a rapid decrease of displacements in the edges, because of the drag from the lateral moraine. It implies that basal sliding is the more dominant trigger for the displacement that occurs in the ablation zone.

5 Thermal induced fracturing and development of drainage networks in the previous wet season can enhance the penetration of meltwater from the supraglacial layer to the subglacial layer for lubrication (basal sliding) in the base of a glacier. Consequently, lubrication will result in the basal sliding becoming the dominant factor of ice flow in this status, which then, drives the transportation of the ice mass at a high and relatively conLisheng glaciers is that the reduction of displacements recorded in the ablation zone is large and continuous between 1993-2003 and 2003-2009. However some variations of the displacement are also often recorded on the Xibu, Lalong, Zhadang, and Tangse No. 2 glaciers. Nevertheless, the recorded variations of displacements do not occupy 15 such continuous proportions on the rest of the eight glaciers compared with the observations on the Guila, Guren, Panu and Lisheng glaciers (see Fig. 9). Then, the smaller surface displacements (about $<30 \mathrm{~m}$ ), are also measured from the lower ablation zone to the higher accumulation zone on the Guila, Guren, Panu and Lisheng glaciers. In terms of the glacial displacement determination described above, it is suggested that both the small variations of the displacements detected within Xibu, Lalong, Zhadang, and Tangse No. 2 glaciers and parts of Guila, Guren, Panu and Lisheng glaciers tend to be interpreted as being more dominated by internal deformation.

\section{Conclusions}

Our research shows that ice surface displacements of the polythermal glaciers in the 25 Nyainqêntanglha Mountains are obtained by phase correlation based feature-tracking method. We have estimated the spatial distributions and temporal variations of glacier displacements during 1993-2009. It is clear that the estimated areas of these eight

\section{HESSD}

$11,1555-1581,2014$

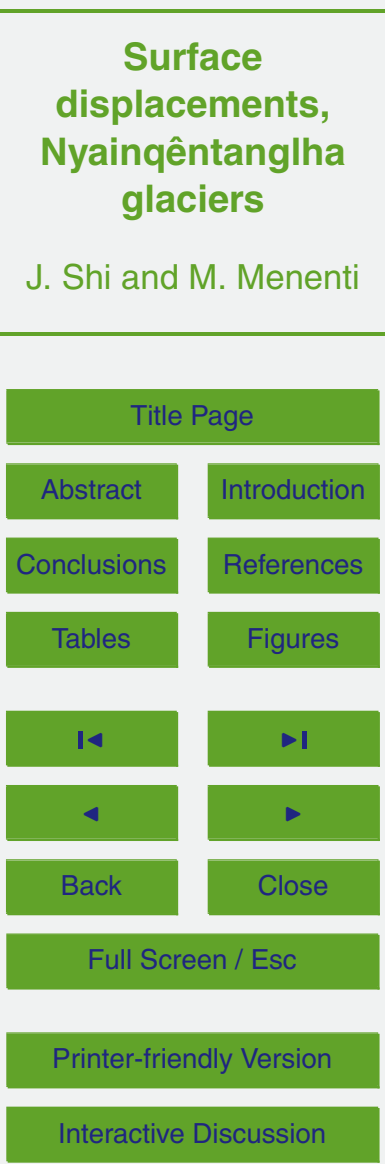

Interactive Discussion 
glaciers are all active, even in their upper regions where the temperatures are considerably low in the winter season. All the displacement observations indicate that the dominant factor of ice fluxes in the studied area varies from the down-glacier to the up-glacier regions.

$5 \quad$ As a next step, we will be estimating the glacier motions with respect to the long term regional climatic variability around the Nyainqêntanglha Mountains in terms of this periodic displacement fluctuations discussed here. We will focus specially on comparing the tendency of the velocities with the tendency of the local average temperature and the precipitation records in the meteorological stations. Furthermore, we will be working on establishing a dataset of the ice surface velocities of these most studied glaciers in the Nyainqêntanglha Mountains since the 1990s of the last century. It will be constructive to explore whether the controller of ice fluxes, discussed here is mainly caused by thermal, or other impact factors. Finally, such a study will be a consistent source, when it is combined with other in situ-measurements, for future glaciological 15

Aschwanden, A. and Blatter, H.: Mathematical modeling and numerical simulation of polythermal glaciers, J. Geophys. Res., 114, F01027, doi:10.1029/2008JF001028, 2009. 1557

Bindschadler, R. and Scambos, T.: Satellite-image-derived velocity field of an Antarctic ice stream, Science, 252, 242-246, 1991. 1560

25 Blatter, H. and Hutter, K.: Polythermal conditions in Arctic glaciers, J. Glaciol., 37, 261-269, 1991. 1557, 1565

Bolch, T., Yao, T., Kang, S., Buchroithner, M. F., Scherer, D., Maussion, F., Huintjes, E., and Schneider, C.: A glacier inventory for the western Nyainqentanglha Range and the Nam Co

HESSD

$11,1555-1581,2014$

Surface

displacements,

Nyainqêntanglha

glaciers

J. Shi and M. Menenti

Title Page

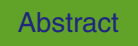

Introduction

Conclusions

Tables

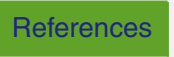
2007-1 Grant 212921) as part of the CEOP-AEGIS project. The ASTER GDEM data and Landsat imageries were acquired from LA DAAC, USGS. COSI-Corr was supplied by S. Leprince and his colleagues from the Tectonics Group at California Institute of Technology.

\section{4}

4

Back

Full Screen / Esc

Printer-friendly Version

Interactive Discussion
Figures

I

$>$

Close 
Basin, Tibet, and glacier changes 1976-2009, The Cryosphere, 4, 419-433, doi:10.5194/tc4-419-2010, 2010. 1558, 1564, 1565

Caidong, C. and Asgeir, S.: Modelled mass balance of Xibu glacier, Tibetan Plateau: sensitivity to climate change, J. Glaciol., 56, 235-248, 2010. 1563, 1565

5 Chander, G., Markham, B. L., and Helder, D. L.: Summary of current radiometric calibration coefficients for Landsat MSS, TM, ETM+, and EO-1 ALI sensors, Remote Sens. Environ., 113, 893-903, 2009. 1560

Copland, L., Sharp, M. J., and Nienow, P. W.: Links between short-term velocity variations and the subglacial hydrology of a predominantly cold polythermal glacier, J. Glaciol., 49, 337-

10 348, 2003. 1557

Copland, L., Pope, S., Bishop, M. P., Shroder, J. F., Clendon, P., Bush, A., Kamp, U., Seong, Y. B., and Owen, L. A.: Glacier velocities across the central Karakoram, Ann. Glaciol., 50, 41-49, 2009. 1561

Doake, C. and Vaughan, D.: Rapid disintegration of the Wordie Ice Shelf in response to atmopsheric warming, Nature, 350, 328-330, 1991. 1560

Fowler, A. and Larson, D.: On the flow of polythermal glaciers, II. Surface wave analysis, P. Roy. Soc. Lond. A Mat., 370, 155-171, 1980. 1557

Heid, T. and Kääb, A.: Evaluation of existing image matching methods for deriving glacier surface displacements globally from optical satellite imagery, Remote Sens. Environ., 118, 339355, 2012. 1560, 1561, 1563

Huang, M.: On the temperature distribution of glaciers in China, J. Glaciol., 36, 210-216, 1990. 1558

Hutter, K.: A mathematical model of polythermal glaciers and ice sheets, Geophys. Astro. Fluid, 21, 201-224, 1982. 1557

Hutter, K., Blatter, H., and Funk, M.: A model computation of moisture content in polythermal glaciers, J. Geophys. Res., 93, 12205-12214, 1988. 1557

Kang, S., Chen, F., Gao, T., Zhang, Y., Yang, W., Yu, and W., Yao, T.: Glacier retreating dramatically on Mt. Nyainqêntanglha during the last 40 years, Journal of Glaciology and Geocryology, 29, 869-873, 2007. 1558, 1563, 1565

30 Kang, S., Chen, F., Ye, Q., Jing, Z., Qin, D., and Ren, J.: Early onset of rainy season suppresses glacier melt: a case study on Zhadang glacier, Tibetan Plateau, J. Glaciol., 55, 755-758, 2009. 1564

\section{HESSD}

11, 1555-1581, 2014

Surface

displacements,

Nyainqêntanglha

glaciers

J. Shi and M. Menenti

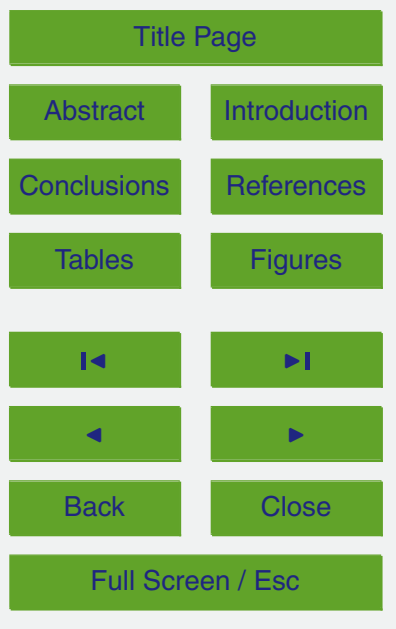

Printer-friendly Version

Interactive Discussion 
Leprince, S., Barbot, S., Ayoub, F., and Avouac, J.-P.: Automatic and precise orthorectification, coregistration, and subpixel correlation of satellite images, application to ground deformation measurements, IEEE T. Geosci. Remote, 45, 1529-1558, 2007. 1561, 1563

Leprince, S., Muse, P., and Avouac, J.-P.: In-flight CCD distortion calibration for pushbroom 5 satellites based on subpixel correlation, IEEE T. Geosci. Remote, 46, 2675-2683, 2008. 1561

Lucchitta, B. and Ferguson, H.: Antarctica: measuring glacier velocity from satellite images, Science, 234, 1105-1108, 1986. 1560

Markham, B., Storey, J., Williams, D. L., and Irons, J.: Landsat sensor performance: history and current status, IEEE T. Geosci. Remote, 42, 2691-2694, doi:10.1109/TGRS.2004.840720, 2004. 1559

Quincey, D., Copland, L., Mayer, C., Bishop, M., Luckman, A., and Belo, M.: Ice velocity and climate variations for Baltoro Glacier, Pakistan, J. Glaciol., 55, 1061-1071, 2009a. 1561

Quincey, D., Luckman, A., and Benn, D.: Quantification of Everest region glacier velocities be15 tween 1992 and 2002, using satellite radar interferometry and feature tracking, J. Glaciol., 55, 596-606, 2009b. 1561

Quincey, D. J., Braun, M., Glasser, N. F., Bishop, M. P., Hewitt, K., and Luckman, A.: Karakoram glacier surge dynamics, Geophys. Res. Lett., 38, L18504, doi:10.1029/2011GL049004, 2011. 1561

20 Scambos, T. A., Dutkiewicz, M. J., Wilson, J. C., and Bindschadler, R. A.: Application of image cross-correlation to the measurement of glacier velocity using satellite image data, Remote Sens. Environ., 42, 177-186, 1992. 1560

Scherler, D. and Strecker, M.: Large surface velocity fluctuations of Biafo Glacier, central Karakoram, at high spatial and temporal resolution from optical satellite images, J. Glaciol., 58, 569-580, 2012. 1561

Scherler, D., Leprince, S., and Strecker, M. R.: Glacier-surface velocities in alpine terrain from optical satellite imagery - accuracy improvement and quality assessment, Remote Sens. Environ., 112, 3806-3819, 2008. 1561

Scherler, D., Bookhagen, B., and Strecker, M. R.: Spatially variable response of Himalayan glaciers to climate change affected by debris cover, Nat. Geosci., 4, 156-159, 2011. 1561

Shi, Y. and Liu, S.: Estimation on the response of glaciers in China to the global warming in the 21st century, Chinese Sci. Bull., 45, 668-672, 2000. 1557, 1563
HESSD

$11,1555-1581,2014$

Surface

displacements,

Nyainqêntanglha

glaciers

J. Shi and M. Menenti

Title Page

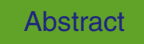

Introduction

Conclusions

Tables

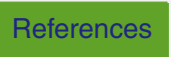

Figures

14

4

Back

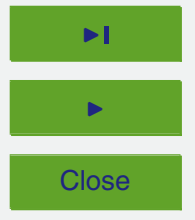

Full Screen / Esc

Printer-friendly Version

Interactive Discussion 
Shi, Y., Liu, C., and Kang, E.: The Glacier Inventory of China, Ann. Glaciol., 50, 1-4, 2009. 1557, 1558, 1564

Vogelmann, J. E., Helder, D., Morfitt, R., Choate, M. J., Merchant, J. W., and Bulley, H.: Effects of Landsat 5 thematic mapper and Landsat 7 enhanced thematic mapper plus radiometric and geometric calibrations and corrections on landscape characterization, Remote Sens. Environ., 78, 55-70, 2001. 1559

Wang, Z. and Yang, H.: Characteristics of the distribution of glaciers in China, Ann. Glaciol., 16, 17-20, 1992. 1558

Williams, D. L., Goward, S., and Arvidson, T.: Landsat, Photogramm. Eng. Rem. S., 72, 11711178, 2006. 1559

Wulder, M. A., White, J. C., Goward, S. N., Masek, J. G., Irons, J. R., Herold, M., Cohen, W. B., Loveland, T. R., and Woodcock, C. E.: Landsat continuity: issues and opportunities for land cover monitoring, Remote Sens. Environ., 112, 955-969, 2008. 1560

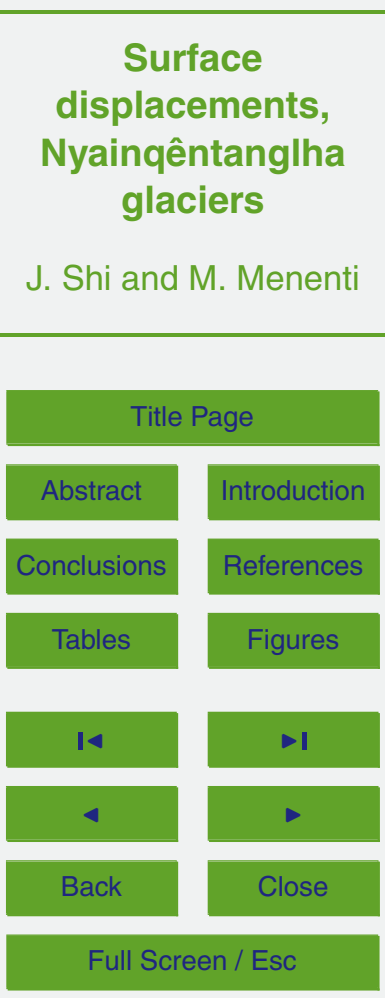

Printer-friendly Version

Interactive Discussion 
HESSD

11, 1555-1581, 2014

\section{Surface}

displacements, Nyainqêntanglha

glaciers

Table 1. The glaciological features of the eight polythermal glaciers of interest in the study area, $S_{\mathrm{t}}, L_{\mathrm{t}}, \bar{D}, V$ represents the total area, the total length, the mean of the depth and the volume, respectively.

\begin{tabular}{lccccrrrr}
\hline & Zhadang & Panu & Lalong & Tangse No. 2 & Xibu & Lisheng & Guila & Guren \\
\hline$S_{\mathrm{t}}\left(\mathrm{km}^{2}\right)$ & 2.48 & 12.88 & 10.29 & 2.96 & 23.35 & 4.4 & 14.69 & 5.6 \\
$L_{\mathrm{t}}(\mathrm{km})$ & 2.7 & 5.3 & 3.6 & 2.1 & 9.3 & 4.2 & 7.2 & 4.2 \\
$\bar{D}(\mathrm{~m})$ & 59 & 102 & 86 & 69 & 139 & 48 & 108 & 78 \\
$V\left(\mathrm{~km}^{3}\right)$ & 0.15 & 1.26 & 0.64 & 0.27 & 4.39 & 0.07 & 1.59 & 0.44 \\
\hline
\end{tabular}

J. Shi and M. Menenti

Title Page

Abstract

Introduction

Conclusions

References

Tables

Figures

14

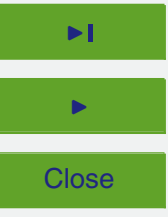

Back

Full Screen / Esc

Printer-friendly Version

Interactive Discussion 


\section{HESSD}

$11,1555-1581,2014$

\section{Surface}

displacements, Nyainqêntanglha glaciers

J. Shi and M. Menenti

Table 2. It shows the statistics of displacement changes of these sampled glaciers in the study area, $\Delta \overline{\mathrm{Ds}}$ represents the increment of the displacement (\%).

\begin{tabular}{lcccccrrr}
\hline & Zhadang & Panu & Lalong & Tangse No. 2 & Xibu & Lisheng & Guila & Guren \\
\hline Displacement pixels (1993-2003) & 422 & 1553 & 892 & 412 & 3376 & 1806 & 519 & 688 \\
Displacement pixels(2003-2009) & 422 & 1502 & 1084 & 441 & 3113 & 1806 & 519 & 688 \\
Displacement pixels (for comparison) & 422 & 1502 & 892 & 412 & 3113 & 1806 & 519 & 688 \\
$\Delta \overline{\mathrm{Ds}}(\%)$ & -49 & -20 & -58 & -63 & +24 & -61 & -44 & -65 \\
\hline
\end{tabular}

Title Page

Abstract Introduction

Conclusions

References

Tables

Figures

14

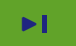

4

Back

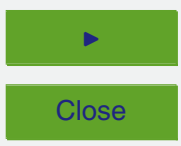

Full Screen / Esc

Printer-friendly Version

Interactive Discussion 


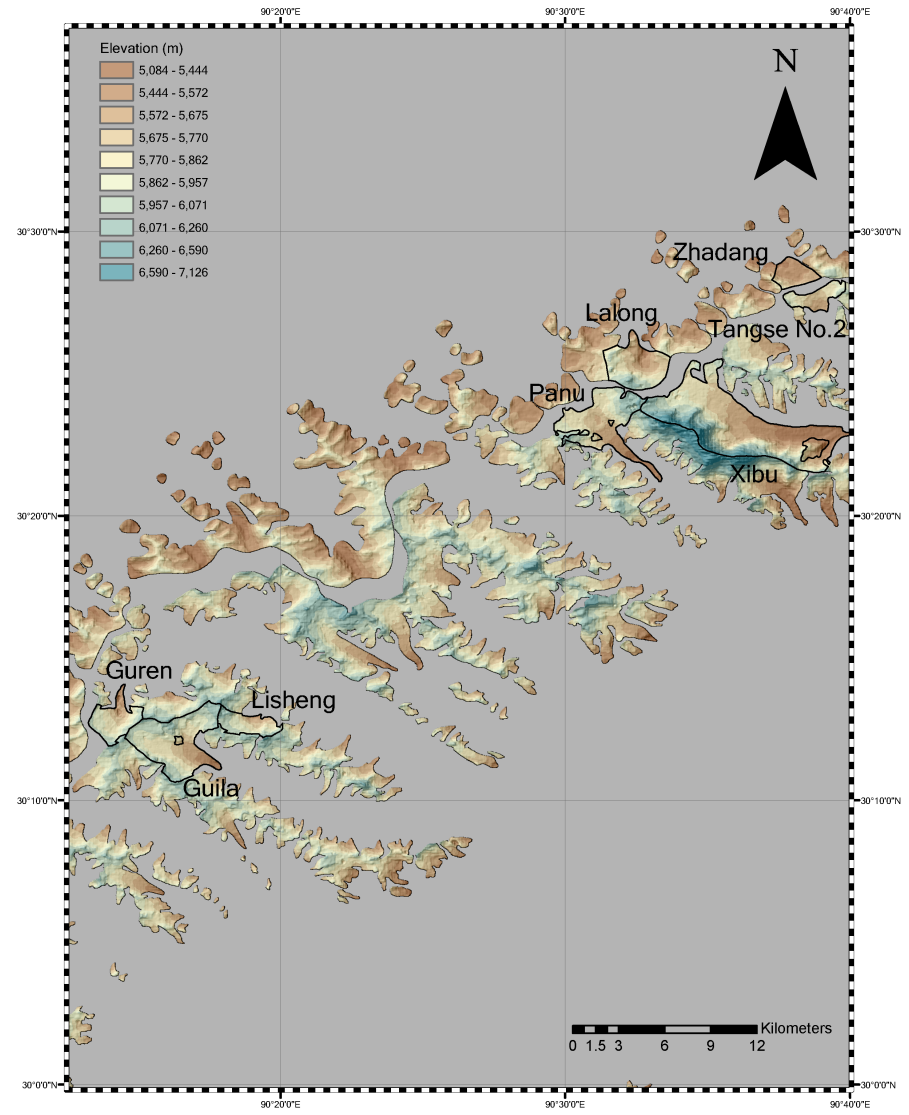

Fig. 1. The general geolocations of the studied polythermal glaciers in the study area based on the CGI (Chinese Glacier Inventory). The color rendered relief is the elevation of the glaciated surface derived from ASTER GDEM.

\section{HESSD}

$11,1555-1581,2014$

\section{Surface \\ displacements, Nyainqêntanglha glaciers}

J. Shi and M. Menenti

Title Page

Abstract Introduction

Conclusions

References

Tables

Figures

14

$\rightarrow 1$

$<$

Back

Close

Full Screen / Esc

Printer-friendly Version

Interactive Discussion 


\section{HESSD}

$11,1555-1581,2014$

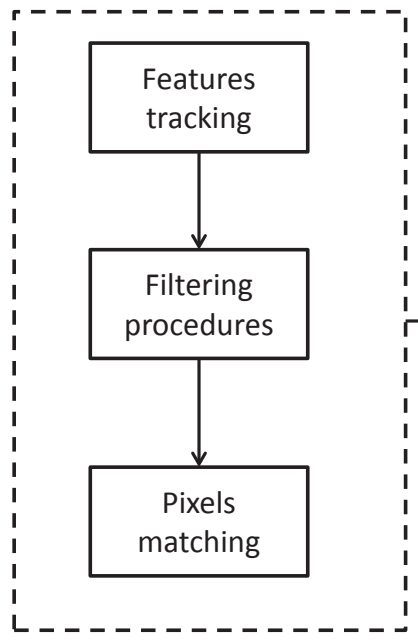

Part I: Displacement extraction

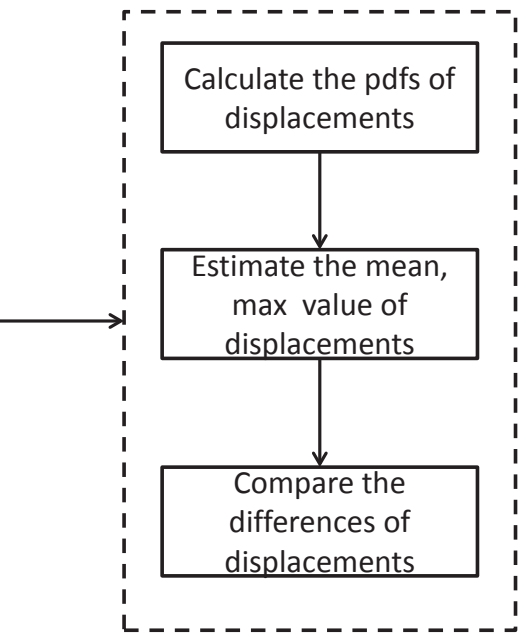

Part II: Estimation of displacements differences

Fig. 2. This diagram shows the procedures of the analysis of ice surface displacement variations in this study.

\section{Surface \\ displacements, Nyainqêntanglha glaciers}

\section{J. Shi and M. Menenti}

\section{Title Page}

Abstract Introduction

Conclusions

References

Tables

Figures

14

-1

4

Back

Close

Full Screen / Esc

Printer-friendly Version

Interactive Discussion 


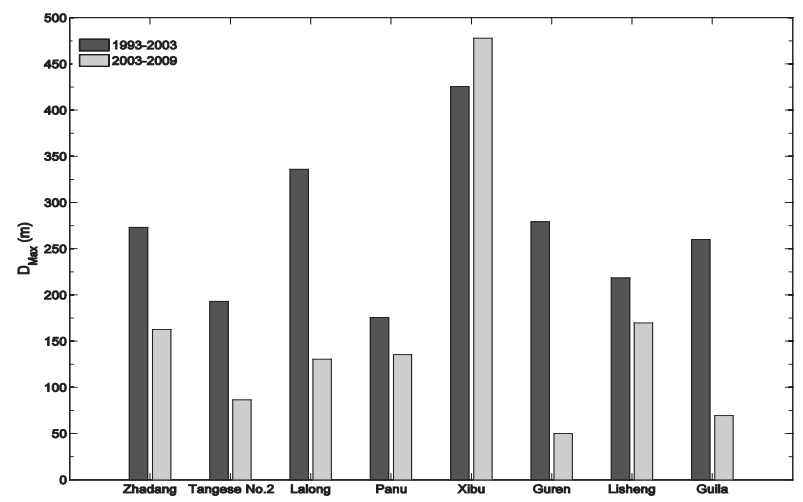

HESSD

11, 1555-1581, 2014

(a)

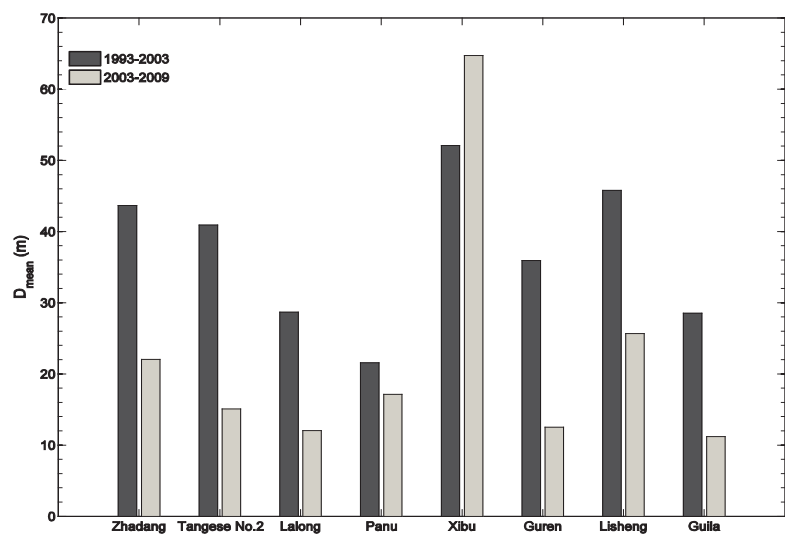

Title Page

Abstract

Introduction

displacements, Nyainqêntanglha

glaciers

J. Shi and M. Menenti

Conclusions

References

Tables

Figures

14

I

$<$

Back

Close

Full Screen / Esc

Printer-friendly Version

Fig. 3. Comparison of the studied polythermal glaciers. The largest displacements of these two periods are shown in (a), and the averages of the displacements are shown in (b). The black columns indicate the observed displacement value during 1993-2003 and the gray columns indicate the observed displacement value during 2003-2009. 


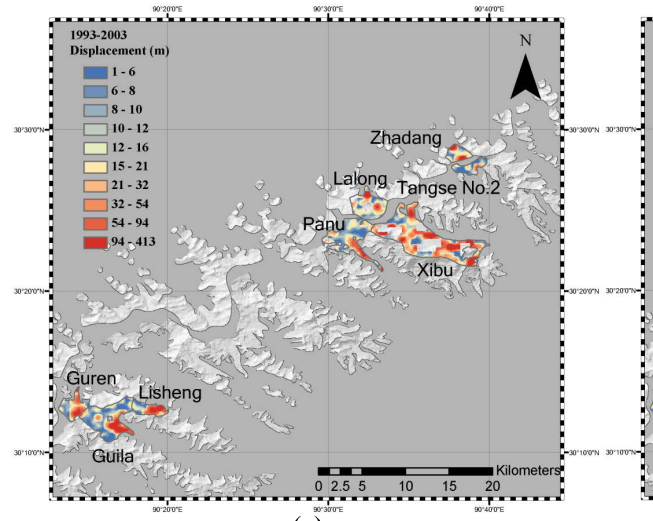

(a)

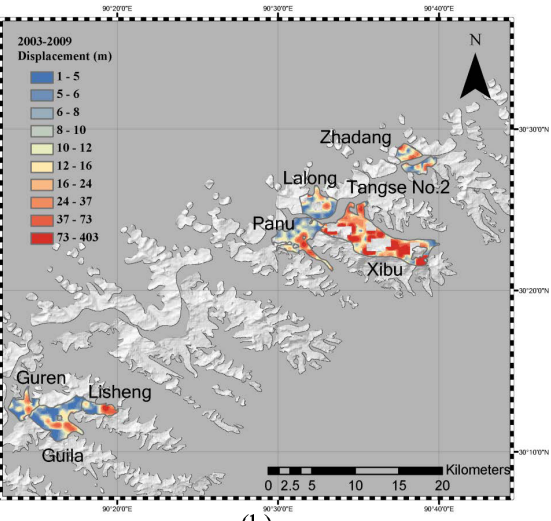

(b)

Fig. 4. The ice surface displacements of the studied polythermal glaciers in the Nyainqêntanglha Mountains, acquired during the periods of 1993-2003 and 2003-2009, respectively. The gray background is the ground relief of the glaciated area, the color rendered area is the displacement of the glacier surface in that period.

\section{HESSD}

$11,1555-1581,2014$

\section{Surface \\ displacements, Nyainqêntanglha glaciers}

J. Shi and M. Menenti

Title Page

Abstract Introduction

Conclusions

References

Tables

Figures

14

$<$

Back

Close

Full Screen / Esc

Printer-friendly Version

Interactive Discussion 

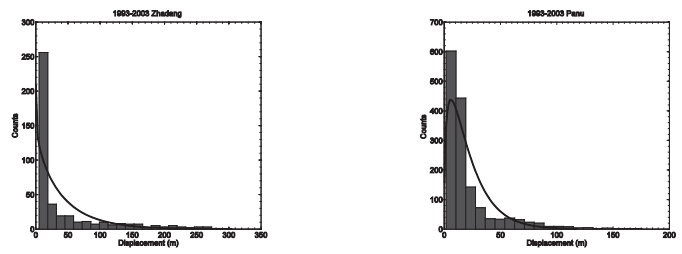

(a)

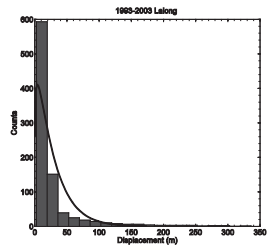

(c)

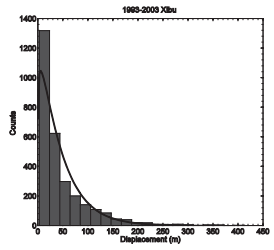

(e)

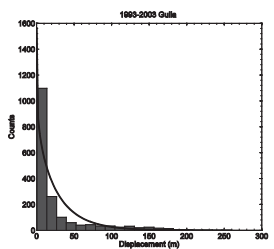

(g)

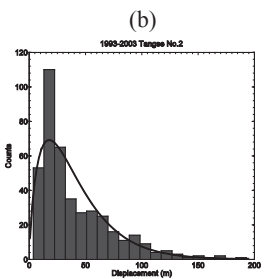

(d)

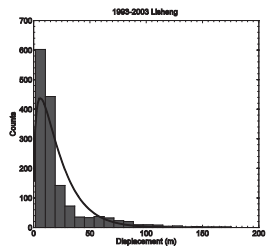

(f)

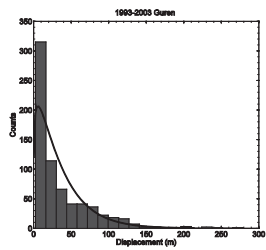

(h)

Fig. 5. The PDF (probability density function) of derived surface displacements are calculated from 1993 to 2003 for all the polythermal glaciers (Zhadang, Panu, Lalong, Tangse No. 2, Xibu, Lisheng, Guila, and Guren).

HESSD

$11,1555-1581,2014$

\section{Surface}

displacements, Nyainqêntanglha glaciers

\section{J. Shi and M. Menenti}

Title Page

Abstract Introduction

Conclusions References

Tables Figures

14 I

$<$

\section{Back}

Close

\section{Full Screen / Esc}

Printer-friendly Version

Interactive Discussion 


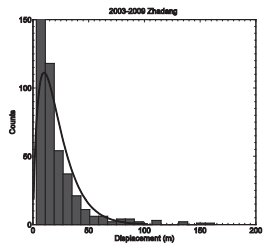

(a)

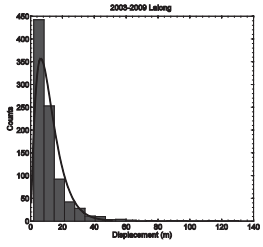

(c)

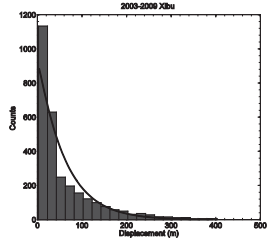

(e)

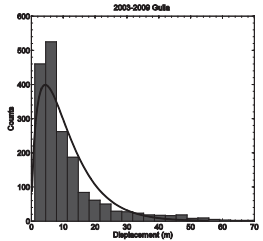

(g)

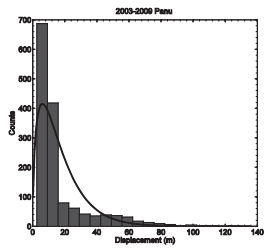

(b)

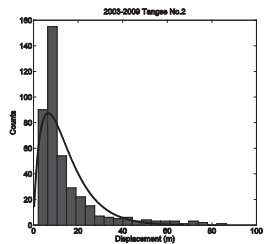

(d)

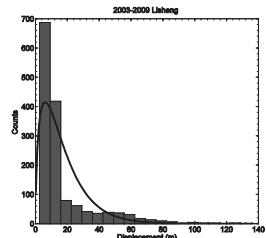

(f)

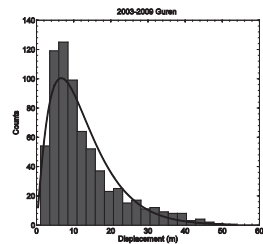

(h)

Fig. 6. The PDF (probability density function) of derived surface displacements are calculated from 2003 to 2009 for all the polythermal glaciers (Zhadang, Panu, Lalong, Tangse No. 2, Xibu, Lisheng, Guila, and Guren). 


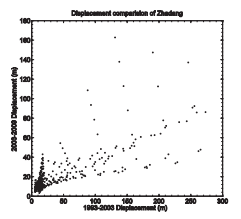

(a)

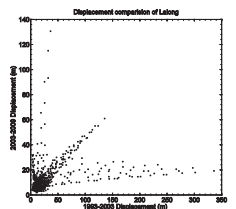

(c)

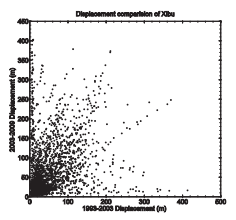

(e)

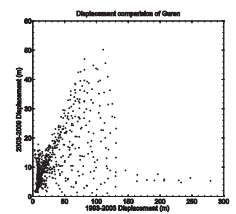

(g)

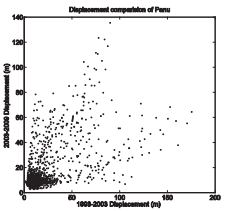

(b)

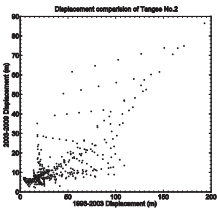

(d)

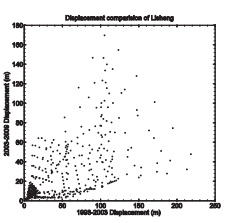

(f)

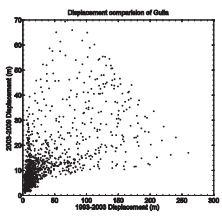

(h)

Fig. 7. The comparison of the surface displacements between two periods: (1993-2003), (2003-2009). Due to all displacements derived from the same pixel on each glacier, a lot of displacements change considerably apart from the clustering trends are found in the relative low magnitude area.

\section{HESSD}

$11,1555-1581,2014$

\section{Surface}

displacements, Nyainqêntanglha

glaciers

\section{J. Shi and M. Menenti}

\section{Title Page}

Abstract

Introduction

Conclusions

References

Tables

Figures

14

$>1$

4

Back

Close

\section{Full Screen / Esc}

Printer-friendly Version

Interactive Discussion 

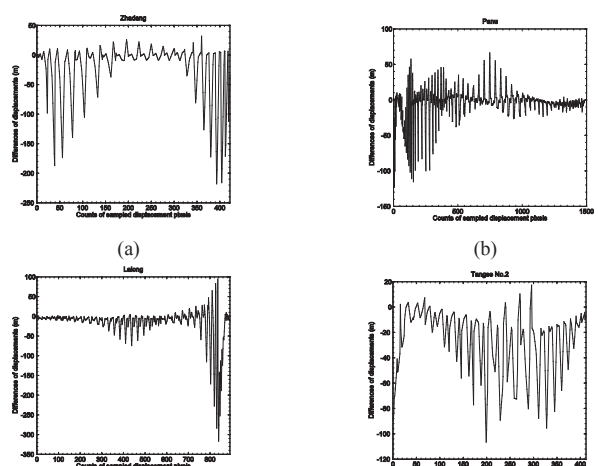

(c)

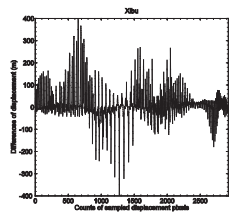

(e)

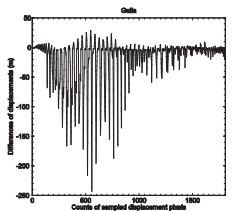

(g) (b)

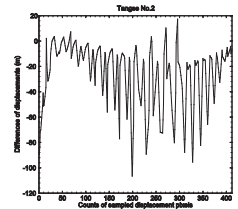

(d)

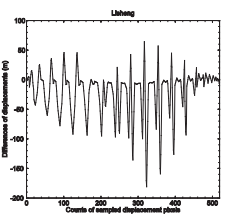

(f)

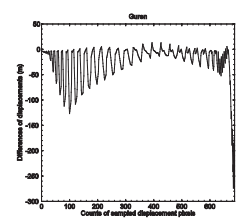

(h)

Fig. 8. The differences of the surface displacements between two periods: (1993-2003), (20032009). Except Xibu glacier, the differences of the surface displacements on the other studied glaciers indicate a decreasing trends for the changes of displacements from (1993-2003) to (2003-2009).

\section{HESSD}

$11,1555-1581,2014$

\section{Surface}

displacements, Nyainqêntanglha

glaciers

\section{J. Shi and M. Menenti}

\section{Title Page}

Abstract

Introduction

Conclusions

References

Tables

Figures

14

$>1$

4

Back

Close

\section{Full Screen / Esc}

Printer-friendly Version

Interactive Discussion 


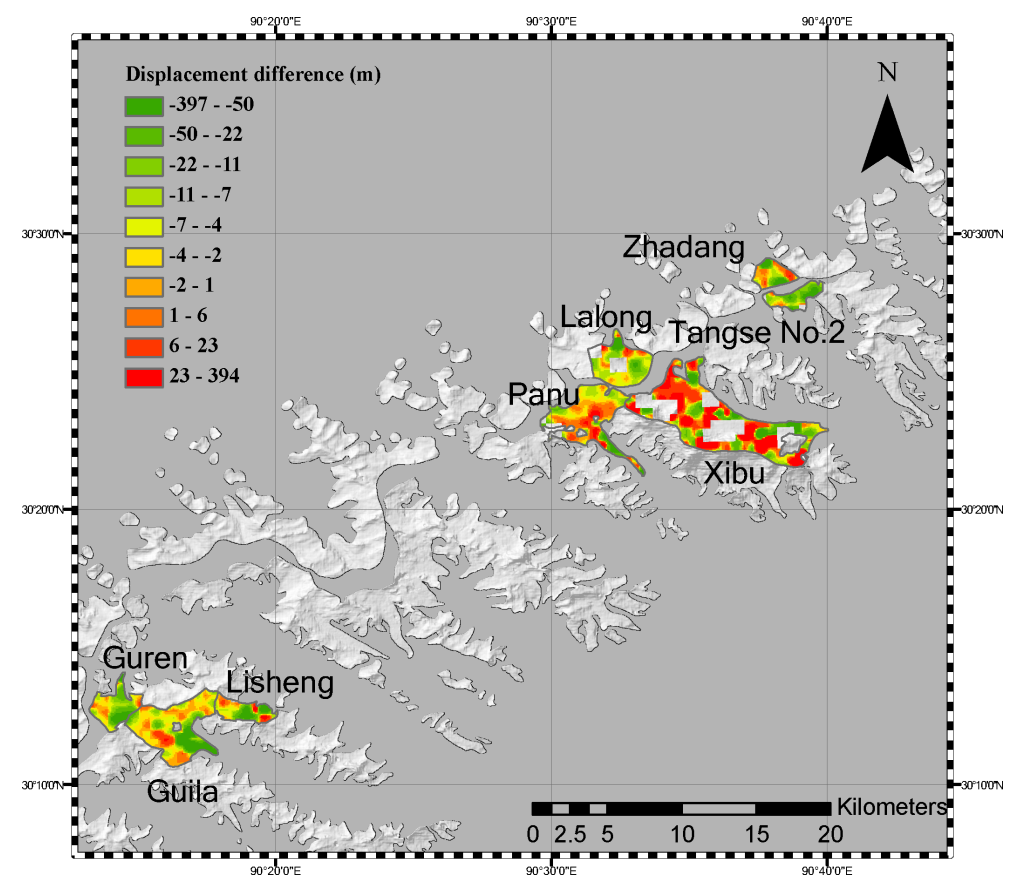

Fig. 9. The displacement differences of the studied polythermal glaciers in the Nyainqêntanglha Mountains, acquired during the periods of 1993-2003 and 2003-2009, respectively. The gray background is the ground relief of the glaciated area, the color rendered area is the displacement of the glacier surface in that period.

\section{HESSD}

$11,1555-1581,2014$

\section{Surface \\ displacements, Nyainqêntanglha glaciers}

\section{J. Shi and M. Menenti}

\section{Title Page}

\section{Abstract}

Introduction

Conclusions

References

Tables

Figures

14

$\rightarrow 1$

Back

\section{Full Screen / Esc}

Printer-friendly Version

Interactive Discussion 